\title{
Aktivitas Antioksidan dan Kandungan Total Fenolik pada Ekstrak Teripang di Perairan Karimunjawa, Jepara
}

\author{
Yolanda Avigail ${ }^{\star}$, Ervia Yudiati, Delianis Pringgenies \\ Departemen IImu Kelautan, Fakultas Perikanan dan IImu Kelautan, Universitas Diponegoro \\ JI. Prof.H.Soedarto S.H, Tembalang,Semarang, Jawa Tengah 50275 Indonesia \\ *Corresponding author, e-mail :yolandavigail@gmail.com
}

\begin{abstract}
ABSTRAK : Teripang merupakan hewan jenis Echinodermata. Beberapa species teripang, misalnya $H$. scabra, $H$. fuscogilva dan $T$. ananas memiliki nilai jual yang tinggi. Meskipun tidak semua spesies memiliki nilai jual yang tinggi, teripang berpotensi untuk dikembangkan dalam bidang kesehatan, terutama dalam kemampuannya untuk meredam radikal bebas dan mencegah berbagai penyakit degeneratif. Tujuan dari penelitian ini yaitu untuk mengidentifikasi, menentukan aktivitas antioksidan, kandungan total fenol, serta kadar karotenoid pada ekstrak beberapa teripang yang berasal dari Perairan Karimunjawa Jepara. Hasil identifikasi dari ke empat spesies adalah Stichopus cf. quadrifasciatus, Pearsonothuria graeffei, Bohadschia vitiensis, dan Holothuria atra. Ekstraksi dilakukan dengan teknik maserasi dinding tubuh teripang menggunakan pelarut metanol. Uji aktivitas antioksidan dilakukan dengan menggunakan metode DPPH (1,1-difenilpikrilhidrazil) sebagai agen radikal bebas. Penentuan total fenolik dilakukan menggunakan metode folin-ciocalteu, dan penentuan kadar karotenoid dilakukan dengan menggunakan spektrofotometer. Hasil menunjukkan bahwa aktivitas antioksidan Bohadschia vitiensis, Stichopus cf. quadrifasciatus, Pearsonothuria graeffei, dan Holothuria atra tergolong sangat lemah dengan nilai $\mathrm{IC}_{50}$ secara berturut-turut adalah sebesar $454,28 \pm 14,4 ; 713,51 \pm 9,1 ; 801,57 \pm 8,4$ dan 1535,47 ppm. Kandungan total fenol sebesar $21,08 \pm 0,49 ; 14,325 \pm 0,21 ; 14,033 \pm 0,33$ dan $10,67 \pm 0,12 \mathrm{mg}$ GAE/g sampel, dan kadar karotenoidnya sebesar $23,28 \pm 0,07 ; 25,78 \pm 0,56 ; 11,85 \pm 0,04$; dan $41,44 \pm 0,008 \mu \mathrm{mol} / \mathrm{g}$ sampel.
\end{abstract}

Kata kunci: Teripang, Antioksidan, DPPH, Fenolik, Karotenoid

\section{Antioxidant Activity and Total Phenolic Content From Extract Sea Cucumber in Karimunjawa Island, Jepara}

\begin{abstract}
Sea cucumbers are sea benthos from phylum Echinoderms phylum. Some sea cucumbers such as $H$. scabra, $H$. fuscogilva, T. Ananas have a high economical price. Eventhough, some sea cucumbers have the potency of being a healthy food. It it scientifically proven that some sea cucumbers have the ability to reduce free radicals and prevent various degenerative diseases caused by the excessive free radicals. The aims of this study were to identified, determine antioxidant activity, total phenol content, and carotenoid levels in sea cucumber extracts originally from Karimunjawa waters. Some of the sea cucumbers obtained are Stichopus cf. quadrifasciatus, Pearsonothuria graeffei, Bohadschia vitiensis, and Holothuria atra. The extraction was done by macerating the body walls with methanol. The antioxidant activity test were tested using the DPPH method as free radicals, the total phenolic content tested using the folin-ciocalteu method, and determined the carotenoid levels spectrophotometrically. Based on the results, antioxidant activity of $B$. vitiensis, $S$. cf. quadrifasciatus, $P$. graeffei, and $H$. atra were classified as very weak with $I C_{50} 454.28 \pm 14.4 ; 713.51 \pm 9.1 ; 801.57 \pm 8.4$ dan 1535.47 ppm. Total phenolic content were $21.08 \pm 0.49 ; 14.325 \pm 0.21 ; 14.033 \pm 0.33$ dan $10.67 \pm 0.12 \mathrm{mg}$ GAE/g samples, while carotenoid levels were $23.28 \pm 0.07 ; 25.78 \pm 0.56 ; 11.85 \pm 0.04 ;$ dan $41.44 \pm 0.008 \mu \mathrm{mol} / \mathrm{g}$ sample.
\end{abstract}

Keyword : Sea cucumber, Antioxidant, DPPH, Phenolic, Carotenoid 


\section{PENDAHULUAN}

Radikal bebas adalah senyawa yang bersifat sangat reaktif karena mudah bereaksi dengan molekul lain dengan cara mengoksidasi sehingga dapat menimbulkan pengaruh negatif terhadap tubuh antara lain mengakibatkan kerusakan lipida, protein, DNA dan membran sel. Kerusakankerusakan tersebut dapat memicu timbulnya penyakit degeneratif yaitu kanker, aterosklerosis, diabetes, dan tekanan darah tinggi (Inggrid dan Santoso, 2014). Keberadaan radikal bebas mengakibatkan tubuh memerlukan suatu substansi penting yang mampu menangkap radikal bebas, yaitu antioksidan. Senyawa antioksidan bekerja dengan cara mendonorkan satu elektronnya kepada senyawa radikal bebas, sehingga aktivitas senyawa radikal tersebut dapat dihambat (Saleh et al., 2005). Berdasarkan sumbernya, antioksidan dapat dibagi menjadi antioksidan alami dan sintetik, namun penggunaan beberapa antioksidan sintetik bersifat karsinogenik, sehingga dapat menyebabkan kanker dan mutasi gen (Rita et al, 2009). Antioksidan alami dapat diperoleh dari organisme darat dan laut. Teripang merupakan salah satu produk laut yang memiliki aktivitas antioksidan. Beberapa teripang komersil yang sudah diketahui manfaatnya antara lain Holothuria scabra (teripang putih atau pasir), Holothuria edulis (teripang hitam), Holothuria vacabunda (teripang getah atau keling), Holothuria vatiensis (teripang merah) dan Holothuria marmorata (teripang cokelat), (Stichopus horrens) (Martoyo, 2000).

Senyawa yang terkandung dalam teripang telah terbukti secara ilmiah dapat meredam radikal bebas dan mencegah berbagai penyakit degeneratif yang disebabkan oleh radikal bebas berlebih. Beberapa senyawa diantaranya adalah triterpen glikosida (saponin), kondroitin sulfat, glycosaminoglycans (GAGs), fenolik, dan asam lemak esensial (Soltani et al., 2014). Rasyid (2012) melaporkan bahwa teripang Stichopus hermanii memiliki potensi sebagai antioksidan dengan nilai $\mathrm{IC}_{50} 65,08$ ppm. Penelitian lain yang dilakukan oleh Nobsathian (2016), aktivitas antioksidan pada Holothuria scabra memiliki nilai $I C_{50}$ sebesar $33.77 \pm 0.24 \mathrm{mg} / \mathrm{ml}$.

Penelitian yang telah dilakukan sebelumnya, membuktikan bahwa teripang berpotensi sebagai agen antioksidan. Selain itu, penelitian tentang aktivitas antioksidan pada spesies teripang non komersial yang berasal dari Perairan Karimunjawa belum banyak dilakukan. Di Indonesia, Perairan dan Karimunjawa adalah salah satu lokasi di mana sumber teripang dipanen (Janakiram, Mohammed, \& Rao, 2015; Ridhowati, Zakaria, Syah, \& Chasanah, 2014). Salah satu upaya untuk mengoptimalkan pemanfaatan bahan alam laut Indonesia yaitu melakukan pengujian aktivitas antioksidan pada beberapa teripang yang ditemukan di Karimunjawa.Berdasarkan pertimbangan tersebut maka penelitian ini perlu dilakukan. Tujuan dari penelitian ini yaitu untuk mengidentifikasi, menentukan aktivitas antioksidan, kandungan total fenol, serta kadar karotenoid pada ekstrak beberapa teripang yang berasal dari Perairan Karimunjawa Jepara.

\section{MATERI DAN METODE}

Materi penelitian yang digunakan adalah 4 jenis teripang yaitu Bohadschia vitiensis, Stichopus cf. quadrifasciatus, Pearsonothuria graeffei, dan Holothuria atra yang diambil dari Pancuran Belakang, Karimunjawa. Metode yang digunakan dalam penelitian ini adalah metode eksploratif (Arikunto, 2006). Pengambilan sampel dilakukan dengan metode purposive sampling. Sampel yang didapat dibersihkan dan dibuang isi perutnya, Tahapan penelitian terdiri dari proses identifikasi, ekstraksi, uji aktivitas antioksidan, penentuan kadar total fenolik dan karotenoid.

Teknik identifikasi sampel dilakukan dengan cara mencocokkan gambar yang sudah ada beserta keterangannya (Siddiqi et al., 2017). Pengamatan dilakukan mulai dari bentuk tubuh teripang, warna teripang, dan permukaan tubuh teripang. Buku identifikasi yang digunakan sebagai acuan untuk mencocokkan objek yaitu Commercially Important Sea Cucumbers of The World (Purcell et al., 2012), Katalog Timun Laut Anggota Ordo Aspidochirotida Koleksi Pusat Penelitian Oseanografi LIPI Jakarta (Purwati et al., 2008), dan penelitian oleh Kim et al., (2013).

Ekstraksi dilakukan dengan teknik maserasi dengan perbandingan sampel dan pelarut yaitu 1:1 selama 3x24 jam (Roihanah et al., 2013). Metanol dipilih sebagai pelarut karena metanol dapat mengekstrak senyawa - senyawa dengan kepolaran yang tinggi seperti fenolik (Firdiyani, 2015) dan karotenoid polar. Tidak hanya mengekstrak senyawa yang bersifat polar, tapi juga menyari hampir keseluruhan kandungan simplisia baik non polar, semi polar maupun polar (Iswanti, 2009). Berdasarkan kepolarannya, pelarut metanol juga lebih unggul dibanding dengan etanol, karena 
metanol mempunyai titik didih yang relatif lebih rendah $\left(65^{\circ} \mathrm{C}\right)$ sehingga lebih mudah dalam proses evaporasi dan mengurangi risiko kerusakan senyawa termolabil yang terkandung dalam sampel.

Sampel teripang dipotong kecil-kecil dan ditimbang. Kemudian dimaserasi dengan metanol. Setelah itu esktrak dipekatkan dengan rotary evaporator pada suhu $40^{\circ} \mathrm{C}$ sehingga diperoleh ekstrak kasar.

\section{Uji Aktivitas Antioksidan}

Uji aktivitas antioksidan menggunakan metode DPPH (Brand-Williams, 1995) pada konsentrasi ekstrak 200,400,600, 800 ppm dan sebagai kontrol positif digunakan asam askorbat dengan konsentrasi 2,4,6,8 ppm. Hasil ditunjukkan pada nilai absorbansi dengan menggunakan spektrofotometer dengan panjang gelombang $517 \mathrm{~nm}$. Perhitungan yang digunakan adalah nilai $\mathrm{IC}_{50}$ (Inhibition Concentration) yang diperoleh dari hasil persamaan regresi linier. Semakin kecil nilai $I_{50}$ maka semakin tinggi aktivitas antioksidannya (Molyneux, 2004). Nilai absorbansi dihitung dengan menggunakan rumus berikut (Sánchez-Moreno et al., 1998):

$$
\% \text { inhibisi }=\frac{(A-B)}{\mathrm{B}} \times 100 \%
$$

Keterangan : $\mathrm{A}=$ Absorbansi larutan DPPH; $\mathrm{B}=$ Absorbansi DPPH + Ekstrak

\section{Penetapan Kandungan Total Fenolik}

Uji kadar total fenolik mengacu pada Yangthong et al. (2009). Asam galat sebagai standar dibuat dengan konsentrasi 5, 10, 15, 20 dan 25 ppm. Masing-masing konsentrasi ditambah $5 \mathrm{ml}$ aquades dan $0,5 \mathrm{ml}$ reagen folin ciocalteouo $50 \%(\mathrm{v} / \mathrm{v})$. Campuran didiamkan selama 5 menit kemudian ditambah $\mathrm{Na}_{2} \mathrm{CO}_{3} 5 \%$ p.a sebanyak $1 \mathrm{ml}$. Larutan dihomogenkan lalu diinkubasi dalam kondisi gelap selama 1 jam. Absorbansi sampel diukur dengan spektrofotometer UV-V dengan panjang gelombang $725 \mathrm{~nm}$. Selanjutnya, masing- masing ekstrak metanol teripang diambil sebanyak $5 \mathrm{mg}$, kemudian dilarutkan dalam $2 \mathrm{ml}$ etanol p.a. Larutan ditambahkan $5 \mathrm{~mL}$ aquades dan $0,5 \mathrm{~mL}$ reagen folin ciocalteouo $(\mathrm{v} / \mathrm{v})$. Campuran didiamkan selama 5 menit kemudian ditambah $\mathrm{Na}_{2} \mathrm{CO}_{3} 5 \%$ p.a sebanyak $1 \mathrm{~mL}$. Campuran larutan dihomogenkan lalu diinkubasi dalam kondisi gelap selama 1 jam. Absorbansi sampel diukur dengan spektrofotometer UV-V dengan panjang gelombang yang sama.

\section{Penetapan Kadar Karotenoid}

Uji kadar karotenoid mengacu pada Gross (1991). Masing-masing ekstrak ditimbang sebanyak $10 \mathrm{mg}$ dan dilarutkan dalam $5 \mathrm{~mL}$ aseton p.a sehingga diperoleh larutan ekstrak dengan konsentrasi 2000 ppm. Setiap konsentrasi diukur absorbansinya pada panjang gelombang 645 $\mathrm{nm}, 663 \mathrm{~nm}$, dan $480 \mathrm{~nm}$. Kadar karotenooid dapat dihitung menggunakan rumus sebagai berikut (Gross, 1991)

Karetonoid $\mu \mathrm{mol} / \mathrm{g}$ berat sampel: $\frac{(A 480+0,114 \times A 663-0,638 \times A 645) \times V \times 1000}{112,5 \times 0,1 \times 10}$ Keterangan : A 663 = Absorbansi panjang gel. $663 \mathrm{~nm}$; A $645=$ Absorbansi panjang gel. $645 \mathrm{~nm}$; A 480 = Absorbansi panjang gel. $480 \mathrm{~nm} ; \mathrm{V}=$ Volume ekstrak

\section{HASIL DAN PEMBAHASAN}

Teripang $H$. atra memiliki ciri-ciri seluruh tubuhnya berwarna hitam dan biasa tertutup pasir dengan lingkaran kosong di dua baris di sepanjang permukaan punggung, serta hidupnya pada perairan dangkal dan relatif terbuka (Rowe, 1969). Teripang H.atra yang ditemukan di Pulau Seribu (Elfidasari, 2012) memiliki ciri yang sama, Secara morfologi memiliki penampang tubuh bulat, sisi ventral yang cenderung datar, dan lubang anus yang bulat. Warna tubuh hitam kulit tubuhnya lembut dan tebal. Tipe spikula yang ditemukan di bagian dorsal adalah tipe meja, roset, dan lempeng. Ditemukan di daerah bersubstrat pasir kasar dan tubuhnya diselimuti oleh pasir halus. Pada P. graeffei warna dan corak tubuhnya unik sehingga mudah diidentifikasi. Tubuhnya 
berwarna krem dengan bintik-bintik hitam serta permukaan kasar pada permukaannya. Bentuk tubuhnya sub silindris panjang. Terdapat papilla berbentuk kerucut berwarna putih. Sese dan Wirawati (2018) menambahkan ciri Pearsonothuria yaitu bentuk tubuh sub silindris panjang, warna dasar putih dengan dengan bintik-bintik hitam serta permukaan kasar di bivium, papilla berwarna putih kerucut jarang tersebar di dorsal, podia terletak pada ventral, mulut hampir trivium dikelilingi oleh 24 tentakel peltate besar dan hitam, anus mendekati dorsal dan terdapat tubulus cuvier. Spesies $B$. vitiensis memiliki warna krim kecoklatan, dengan dua garis lebar melintang membatasi dorsal. Podia cenderung terletak di titik yang lebih gelap. Secara karakteristik, spesies ini biasanya mengubur diri di dalam sedimen, dan lebih memilih habitat yang tenang dan berpasir (Kim et al., 2013). Karakter morfologi Bohadschia menurut Sesa dan Wirawati (2018) yaitu bentuk tubuh sub silindris, panjang tubuh $16 \mathrm{~cm}$ papilla hitam bulat tersebar di bivium, podia pada trivium tersebar, mulut ventral, anus hampir dorsal. Pengidentifikasian jenis stichopus cukup sulit dilakukan karena keterbatasan referensi. Namun secara morfologi, stichopus yang didapat mirip dengan Stichopus quadrifasciatus. Menurut Penelitian yang dilakukan oleh Elfidasari et al. (2012), teripang jenis Stichopus quadrifasciatus cenderung mempunyai penampang tubuh berbentuk trapesium. Permukaan ventral tubuh datar dan dorsal tubuh melengkung. Permukaan tubuh memiliki tonjolan papila yang membesar. Tubuhnya memiliki warna dasar kuning dengan beberapa area berwarna abu-abu. Podia ditemukan tersebar di bagian dorsal tubuh dan berwarna putih.

Sampel teripang diekstrak dalam keadaan basah. Setelah dilakukan perendaman dengan metanol didapat rendemen sebesar $0,43 \%$ pada $B$. vitiensis, $S$. cf. quadrifasciatus $0,6 \%, P$. graeffei dan $H$. atra 0,4\%. Nilai rendemen menunjukkan kadar metabolit sekunder yang terkandung pada masing masing sampel. Penelitian lain yang dilakukan oleh Sari (2015), dalam pengekstraksian Holothuria leucospilota basah menggunakan metanol, didapat rendemen sebesar $5,66 \%$. Penelitian lainnya juga dilakukan oleh Tursina (2011) yaitu mengekstrak Holothuria atra dan Bohadschia marmorata dengan rendemen secara berturut turut sebesar $0,9 \%$ dan $0,6 \%$. Perbedaan hasil rendemen ekstrak dari suatu bahan dipengaruhi oleh metode ekstraksi, ukuran simplisia, perbandingan bahan dan pelarut, jenis pelarut, waktu ekstraksi, suhu ekstraksi umur panen, dan perbedaan habitat (Kumar et al., 2011). Ditambahkan oleh Wahyuni dan Widjanarko (2015), faktor-faktor yang mempengaruhi efisiensi ekstraksi senyawa bioaktif meliputi tipe pelarut, suhu, jumlah tahapan ekstraksi, volume pelarut dan ukuran partikel sampel.

Persentase rendemen yang didapat dalam penelitian ini relatif kecil. Hal ini menunjukkan bahwa kandungan senyawa aktif / metabolit sekunder dalam sampel relatif sedikit. Diduga hal ini terjadi karena faktor lingkungan tempat tinggal sampel tersebut sangat ideal bagi teripang, sehingga teripang tersebut tidak banyak memproduksi metabolit sekunder dalam tubuhnya guna mempertahankan hidupnya.

Berdasarkan data hasil pengukuran nilai absorban sampel, dapat dianalisis pengaruh konsentrasi sampel terhadap persentasi aktivitas peredaman radikal DPPH, dimana peningkatan konsentrasi sampel sebanding dengan meningkatnya aktivitas peredaman radikal bebas DPPH.

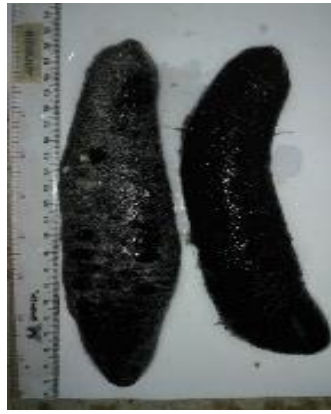

H. atra;

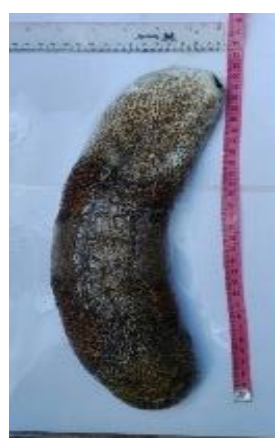

P. graeffei

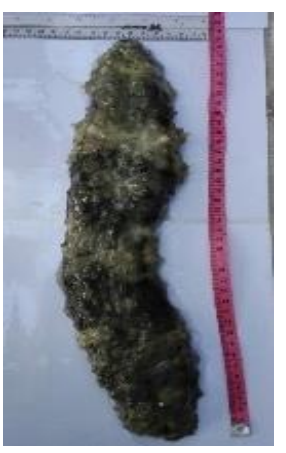

B. vitiensis

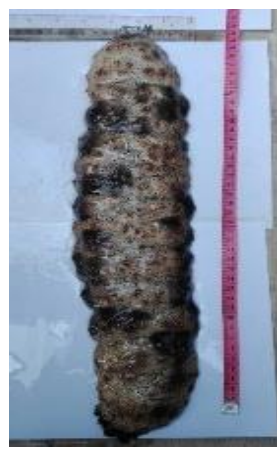

S. cf. quadrifasciatus

Gambar 1. Teripang yang ditemukan di Perairan Karimunjawa 
Tabel 2. Rerata nilai absorbansi, \% inhibisi dan $\mathrm{IC}_{50}$ ekstrak teripang di Karimunjawa

\begin{tabular}{|c|c|c|c|c|c|}
\hline Sampel & $\begin{array}{c}\text { Konsentrasi } \\
\text { (ppm) }\end{array}$ & $\begin{array}{c}\text { Abs. } \\
\text { DPPH }\end{array}$ & $\begin{array}{l}\text { Abs. Sampel } \\
+ \text { DPPH }\end{array}$ & \% Inhibisi & $\mathrm{IC}_{50}(\mathrm{ppm})$ \\
\hline \multirow{4}{*}{$\begin{array}{c}\text { S. cf. } \\
\text { quadrifasciatus }\end{array}$} & 200 & 0,2167 & 0,1527 & 29,64 & $713,51 \pm 9,1$ \\
\hline & 400 & & 0,1437 & 33,79 & \\
\hline & 600 & & 0,1220 & 43,79 & \\
\hline & 800 & & 0,0966 & 55,46 & \\
\hline \multirow[t]{4}{*}{ P.graeffei } & 200 & & 0,2077 & 4,30 & $801,57 \pm+8,40$ \\
\hline & 400 & & 0,1963 & 9,52 & \\
\hline & 600 & & 0,1342 & 38,17 & \\
\hline & 800 & & 0,1100 & 49,30 & \\
\hline \multirow[t]{4}{*}{ B. vitiensis } & 200 & & 0,1541 & 28,97 & $454,28 \pm 14,4^{*}$ \\
\hline & 400 & & 0,1251 & 42,35 & \\
\hline & 600 & & 0,0653 & 69,90 & \\
\hline & 800 & & 0,0577 & 73,42 & \\
\hline \multirow[t]{4}{*}{ H. atra } & 200 & & 0,1730 & 20,04 & $1535,47 \pm 5,93$ \\
\hline & 400 & & 0,1660 & 23,51 & \\
\hline & 600 & & 0,1555 & 28,34 & \\
\hline & 800 & & 0,1440 & 33,62 & \\
\hline \multirow[t]{4}{*}{ Asam askorbat } & 2 & & 0,124 & 42,85 & $4,06 \pm 0,19$ \\
\hline & 4 & & 0,1057 & 51,30 & \\
\hline & 6 & & 0,094 & 56,68 & \\
\hline & 8 & & 0,0881 & 59,41 & \\
\hline
\end{tabular}

Berdasarkan hasil perhitungan, masing - masing ekstrak metanol teripang didapatkan bahwa nilai $\mathrm{IC}_{50}$ pada ekstrak $B$. vitiensis, $S$. cf. quadrifasciatus, $P$. graeffei dan $H$. atra secara berturutturut adalah sebesar 446,09; 733,1767; 736,32; dan 1523,95 ppm. Berdasarkan nilai $I_{50}$ yang ada maka dapat dikategorikan semua teripang uji dikategorikan sebagai antioksidan sangat lemah (Molyneux, 2004). Hal ini kemungkinan disebabkan karena kandungan metabolit sekunder yang terkandung pada ekstrak teripang uji. Teripang uji memiliki metabolit sekunder dengan kadar rendah sehingga menjadi faktor yang mempengaruhi rendahnya aktivitas antioksidan. Faktor yang berpengaruh terhadap kandungan metabolit sekunder pada organisme diantaranya adalah kondisi lingkungan asal sampel. Organisme yang hidup di habitat yang lebih mengancam seperti adanya gelombang besar, paparan sinar matahari, pencemaran dan lain lain memungkinkan suatu organisme tersebut menghasilkan metabolit sekunder untuk bertahan hidup sehingga memiliki potensi antioksidan yang lebih besar. Faktor lain yang mempengaruhi aktivitas antioksidan sampel yaitu ekstrak yang diujikan masih berupa ekstrak kasar (crude extract) yang belum dimurnikan, sehingga senyawa - senyawa lain seperti garam, mineral dan nutrien lain yang tidak memiliki sinergis terhadap kerja antioksidan dapat menghambat kerja senyawa antioksidan. Hal ini berbeda dengan penelitian yang dilakukan oleh Nobsathian (2016) di Thailand. Setelah dilakukan pemurnian senyawa penelitiannya menunjukkan bahwa teripang Holothuria sp. yang diuji memiliki $E_{50}$ sebesar $14,62 \mu \mathrm{g} / \mathrm{ml}$. Penelitian lain tentang aktivitas antioksidan pada teripang juga dilakukan oleh Murniasih et al., (2015) dengan kemampuan meredam radikal sebesar 35,3487\% pada konsentrasi $1 \mathrm{mg} / \mathrm{ml}$. Peneliti lain melaporkan bahwa kedalaman, suhu, intensitas cahaya matahari akan mempengaruhi komposisi pigmen dan senyawa aktif lainnya pada sampel (Jha dan Zhi-rong, 2004). 
Bagian tubuh teripang yang diekstrak juga berpengaruhi terhadap potensi antioksidan. Menurut Mamelona et al. (2007), kemampuan antioksidan pada jeroan lebih baik dibandingkan pada dinding tubuhnya, karena berhubungan dengan makanan yang dimakan oleh teripang itu sendiri, terutama fitoplankton yang banyak mengandung senyawa fenolik.

\section{Penetapan Kadar Total Fenolik}

Penentuan kadar total fenol dilakukan untuk pengujian aktivitas antioksidan karena senyawa fenolik diketahui berperan dalam mencegah terjadinya peristiwa oksidasi (Fitriansyah et al., 2017). Pengukuran ini didasarkan pada pembentukan kompleks molibdenum-tungsten yang terbentuk akibat reduksi fosfomolibdat-fosfotungstat yang terkandung dalam reagen Folin ciocalteu oleh senyawa fenolik yang terdapat dalam sampel. Larutan standar yang digunakan adalah asam galat karena merupakan salah satu senyawa golongan fenolik yang memiliki struktur yang sederhana, substansi yang murni dan stabil.

Hasil uji penentuan kadar total fenol menunjukkan bahwa total fenol pada $B$. vitiensis, $S$. cf. quadrifasciatus, $P$. graeffei dan $H$. atra berturut turut sebesar 21,$08 ; 14,31 ; 14,025$ dan 10,6 mg GAE/g sampel. Hasil ini berbeda dengan hasil penelitan yang dilakukan oleh Wafa et al. (2014) dimana kandungan total fenolik pada ekstrak kasar fraksi metanol Holothuria scabra sebesar 69,09 GAE/g sampel dan fraksi $n$-heksana sebesar $58,01 \mathrm{GAE} / \mathrm{g}$ sampel. Penelitian lain yang dilakukan oleh Mamelona et al. (2007), ekstrak air pada otot Cucumaria frondosa memiliki kandungan fenol sebesar 29,9 GAE/g sampel. Sedangkan pada penelitian Nobsathian (2016), didapati bahwa ekstrak kasar Holothuria scabra yang diuji memiliki kandungan total fenol sebesar $30.52 \pm 0.21$ GAE/g. Adanya perbedaan total fenolik pada ekstrak teripang disebabkan oleh beberapa faktor seperti jenis spesies, geografis, fisiologis dan keadaan lingkungan yang bervariasi (Machu et al., 2015). Faktor lain yang mempengaruh keberadaan fenolik dalam teripang adalah makanan. Sumber utama makanan teripang yang merupakan bahan yang kaya fenolik yaitu fitoplankton dan partikel yang berasal dari makroalga laut, kemungkinan besar mempengaruhi keberadaan senyawa fenolik aktif dalam dinding tubuh teripang (Mamelona et al., 2007).

Rendahnya kadar fenolik dalam teripang menjadi salah satu faktor rendahnya kemampuan senyawa tersebut dalam menghambat radikal bebas DPPH. Terdapat hubungan yang sinergis antara kandungan total fenol dan aktivitas antioksidan. Pada $B$. vitiensis yang memiliki total fenol paling tinggi, mampu merendam radikal bebas lebih besar dibandingkan dengan teripang jenis lain dibuktikan dengan nilai $I_{50}$ yang paling rendah. Hal ini sesuai dengan pernyataan Fitriansyah et al. (2017). Semakin tinggi kadar total fenol pada suatu bahan maka aktivitas antioksidannya akan tinggi, yang ditunjukkan oleh nilai $\mathrm{IC}_{50}$ yang lebih rendah.

\section{Penetapan Kadar Karotenoid}

Senyawa karotenoid juga diduga berpengaruh terhadap aktivitas antioksidan dalam senyawa. Karotenoid adalah pigmen berwarna jingga atau merah. Karotenoid terdiri atas senyawa poliena isoprenoid. Karoten memiliki peran yang menguntungkan bagi kesehatan yakni mempunyai aktivitas sebagai antioksidan, meningkatkan hubungan interselular, immunomodulator dan antikarsinogenik (Supriyono, 2008).

Terdapat perbedaan warna ekstrak yang berbeda dari keempat teripang yang diuji. Stichopus sp., menunjukkan warna oranye, B. vitiensis berwarna kuning terang, $P$. graeffei. berwarna hijau, dan $H$. atra berwarna merah terang. Hal ini diduga karena adanya perbedaan senyawa dan pigmen yang dikandung pada masing - masing teripang. Berdasarkan pengujian kadar karotenoid yang telah dilakukan, menunjukkan bahwa $S$. cf. quadrifasciatus. memiliki kadar karotenoid sebesar 25,78 $\mu \mathrm{mol} / \mathrm{g}$ sampel, $P$. graeffei $11,816 \mu \mathrm{mol} / \mathrm{g}$ sampel, $B$. vitiensis sebesar 23,33 $\mu \mathrm{mol} / \mathrm{g}$ sampel, dan H.atra sebesar $42,84 \mu \mathrm{mol} / \mathrm{g}$ sampel.

Penelitian oleh Chasanah et al. (2016), yang melakukan perbandingan kandungan karotenoid pada teripang di Perairan Karimunjawa jenis Stichopus dan Actinopyga dan teripang di Perairan Lampung jenis Stichopus, Actinopyga dan Holothuria melaporkan bahwa kadar karotenoid pada teripang di Karimunjawa lebih rendah dibanding di Lampung. Ke enam 6 jenis stichopus yang dihitung karotenoidnya bervariasi dengan nilai berkisar 8,72 - 42,25 $\mu \mathrm{mol} / \mathrm{g}$ 
sampel. Jika dibandingkan dengan nilai karotenoid yang dilakukan di penelitian ini, kadar karoten pada Stichopus sp. kurang lebuh sama yaitu sebesar $25,78 \mu \mathrm{mol} / \mathrm{g}$ sampel.

Philip (1975) menyatakan bahwa adanya ikatan rangkap terkonjugasi dalam molekul karotenoid menandakan adanya gugus kromofor yang menyebabkan terbentuknya warna pada karotenoid, Semakin banyak ikatan rangkap terkonjugasi maka semakin pekat warna karotenoid tersebut, yaitu semakin mengarah ke warna merah atau oranye. Kandungan karoten yang terkandung dalam suatu bahan dipengaruhi oleh berbagai faktor, seperti lingkungan (makanan dan intensitas cahaya), jenis, dan lain-lain (Howard et al., 1994). Hasil pengujian total fenolik dan karotenoid yang telah dilakukan menunjukkan kemampuan aktivitas antioksidan yang terkandung dalam ekstrak teripang yang diuji tergolong lemah.

\section{KESIMPULAN}

Berdasarkan hasil penelitian, dapat disimpulkan bahwa aktivitas antioksidan pada ekstrak kasar teripang yang diuji di Perairan Karimunjawa tergolong lemah, sehingga perlu dilakukan uji lebih lanjut mengenai pemanfaatan teripang dalam biofarmasi selain aktivitas antioksidan untuk mengoptimalkan potensi teripang tersebut.

\section{DAFTAR PUSTAKA}

Arikunto, S. 2006. Metode Penelitian Kualitatif. Jakarta: Bumi Aksara

Brand-Williams, W., Cuvelie, M.E., Berset, C. 1995. Use of A Free Radical Method To Evaluate Antioxidant Activity. Lebensmittel-Wissenschaft und Technologie, 28:25-30.

Chasanah, E., Fawzya, Y.N., Tarman, K., Januar, H.I. \& Nursid, M., 2016. Fatty Acid Profile, Carotenoid Content, and In Vitro Anticancer Activity of Karimunjawa and Lampung Sea Cucumber. Squalen Bulletin of Marine and Fisheries Postharvest and Biotechnology, 11(3):117-124.

Elfidasari, D., Noriko, N., Wulandari, N. \& Perdana, A.T., 2012. Identifikasi jenis teripang genus Holothuria asal perairan sekitar Kepulauan Seribu berdasarkan perbedaan morfologi. Jurnal Al-azhar Indonesia seri sains dan teknologi, 1(3):140-146.

Firdiyani, F., Agustini, T.W. \& Ma'ruf, W.F. 2015. Ekstraksi Senyawa Bioaktif Sebagai Antioksidan Alami Spirulina platensis Segar Dengan Pelarut Yang Berbeda. Jurnal Pengolahan Hasil Perikanan Indonesia, 18(1):28-37.

Fitriansyah, S.N., Fidrianny, I. \& Ruslan, K. 2017. Correlation of total phenolic, flavonoid and carotenoid content of Sesbania sesban (L.Merr) leaves extract with DPPH scavenging activities. International Journal of Pharmacognosy and Phytochemical Research. 9(1):89-94. DOI: 10.25258/ijpapr.v9i1.8047

Gross, J. 1991. Pigments in Vegetables. Chlorophylls and Carotenoid. An avi Book. Van Nostrdan Reinhold. New York, p 351.

Howard, L.R., Smith, R.T., Wagner, A.B., Villalon, B. \& Burns, E.E. 1994. Provitamin A and ascorbic acid content of fresh pepper cultivars (Capsicum annuum) and processed jalapenos. Journal Food science. 59, 362-364. DOI: 10.1111/j.1365-2621.1994.tb06967.x

Iswanti, D.A. 2009. Uji Aktivitas Antibakteri Fraksi N-Heksan, Fraksi Etil Asetat, Dan Fraksi Etanol 96\% Daun Ekor Kucing (Acalypha Hispida Burm. F) Terhadap Bakteri Staphylococcus aureus ATCC 25923 Secara Dilusi [skripsi]. Fakultas Farmasi Universitas Setia Budi, Surakata.

Jha, R.K. \& Zi-Rong, X. 2004. Biomedical Compounds from Marine Organism, Marine Drugs, 2:123-146. DOI: $10.3390 / \mathrm{md} 203123$

Kumar, A.P., Graham, H., Robson, C., Garapati, K. and Ghosh, R., 2011. An overview of anticancer herbal medicines. In Evidence-based Anticancer Materia Medica (pp. 1-36). Springer, Dordrecht. DOI: 10.1007/978-94-007-0526-5_1

Machu, L., Misurcova, L., Ambrozova, J. V., Orsavova, J., Mlcek, J., Sochor, J. \& Jurikova, T. 2015. Phenolic Content and Antioxidant Capacity In Algal Food Products. Molecules. (20):1118-1133. DOI: 10.3390/molecules20011118

Mamelona, J., Pelletier, E., Girard-Lalancette, K., Legault, J., Karboune, S., \& Kermasha, S., 2007, Quantification of Phenol Contents and Antioxidant Capacity of Atlantic Sea cucumber, 
Cucumaria frondosa, Food Chemistry, 104(3):1040-1047. DOI: 10.1016/j.foodchem.2007. 01.016

Martoyo, J., Aji, N. \& Winanto, Tj. 2000. Budidaya Teripang. Jakarta: Penebar Swadaya

Molyneux, P. 2004. The Use Of The Stable Free Radical Diphenylpicrylhydrazyl (DPPH) For Estimating Antioxidant Activity. Songklanakarin Journal of Science and Technology. 26:211219.

Murniasih, T., Putra, M.Y. \& Pangestuti, R.. 2015. Antioxidant Activities of Holothuria Sea Cucumbers. Annales Bogorienses, 19(2):21-26

Nobsathian, S., Tuchinda,P., Sobhon, P., Tinikul, Y., Poljaroen, J., Tinikul, R., Sroyraya, M., Poomton, T., \& Chaichotranunt, S. 2016. An Antioxidant Activity of the Methanolic Extract of Black Sea Cucumber. Journal of Traditional Medicine and Clinical Naturopathy, 5(3):1-4. DOI: 10.1186/s40538-017-0087-7

Philip, T. 1975. Carotenoid esters in plant product. Food Technol. 29 (5): 50-54.

Purcell, S.W., Samyn, Y. \& Conand, C. 2012. Comercially Important Sea Cucumber of The World. FAO Species Catalogue for Fishery Purposes. No 6. Rome, Food and Agricukture Organization. $150 \mathrm{pp}$.

Purwati, Pradina \& Wirawati, I. 2008. Synaptidae (Echinodermata: Apodidae) dari Daerah Lamun Elnusa Pulau Timor Nusa Tenggara Timur. Pusat Penelitian Oseanografi, LIPI Jakarta

Rasyid, A. 2012. Identifikasi Senyawa Metabolit Sekunder Serta Uji Aktivitas Antibakteri Dan Antioksidan Ekstrak Metanol Teripang (Stichopus hermanii). Jurnal IImu dan Teknologi Kelautan Tropis. 4(2):360-368.

Rita, A., Tania, S. U., Heri, H, Albana, A. M. \& Rini, R. 2009. Produksi antioksidan dari daun simpur (Dillenia indica) menggunakan metode ekstraksi tekanan tinggi dengan sirkulasi pelarut. Prosiding Seminar Nasional Teknik Kimia Indonesia; Bandung: Perhimpunan Teknik Kimia Indonesia. 1-8 HIm

Roihanah, S., Sukoso \& Andayani. 2012. Aktivitas Antibakteri Ekstrak Teripang Holothuria sp. Terhadap Bakteri Vibrio harveyi Secara In vitro. The Journal of. Experimental Life Science, 2(1):1-5.

Rowe, F.W.E. 1969. A review of the family Holothuriidae (Holothurioidea : Aspidochirotida). Bulletin of the British Museum (Natural History), 18 (4):119-170

Ruswahyuni, Fadli, M. \& Suryanti. 2013. Kelimpahan Jenis Teripang (Holothuroidea) Di Rataan Terumbu Karang Dan Lereng Terumbu Karang Pantai Pancuran Belakang, Pulau Karimunjawa Jepara. Diponegoro Journal of Maquares, 2(3):288-297

Saleh, L. P., Suryanto, E. \& Yudistira, A. 2005. Aktivitas Antioksidan Dari Ekstrak Jagung (Zea mays L.). Jurnal Kimia. 2(4):20-28.

Sánchez-Moreno, C., Larrauri, J.A., \& Saura-Calixto, F. 1998. A Procedure To Measure The Antiradical Efficiency Of Polyphenols. Journal of the Science of Food and Agriculture, 76(2), 270-276. DOI: 10.1002/(SICI)1097-0010(199802)76:2<270::AID-JSFA945>3.0.CO;2-9

Inggrid, H.M. \& Santoso, H. 2014, Ekstraksi Antioksidan dan Senyawa Aktif dari Buah Kiwi (Actinidia deliciosa), Universitas Katolik Parahyangan.

Sari, I.P., M.A. Wibowo, dan S. Arreneuz. 2015. Aktivitas Antibakteri Ekstrak Teripang Butoh Keling (Holothuria leucospilota) Dari Pulau Lemukutan Terhadap Bakteri Propionibacterium acnes dan Staphylococcus epidermidis. Jurnal Kimia Khatulistiwa, 4(4):21-28.

Sese, M.R. \& Wirawati, I.. 2018. Identifikasi Teripang Jenis Pearsonothuria graeffei (Semper, 1868) dan Bohadschia argus (Jaeger, 1833) dari Desa Tandaigi, Parigi Moutong Sulawesi Tengah. Natural Science: Journal of Science and Technology. 7(2):243-251.

Siddiqi, A.A., Sulardiono, Bambang, \& Suryanti. 2017. Struktur Komunitas Teripang (Holothuroidea) di Perairan Pulau Karimunjawa Taman Nasional Karimunjawa, Jepara. In: Prosiding Seminar Nasional Hasil-Hasil Penelitian Perikanan dan Kelautan ke-VI. Fakultas Perikanan dan IImu Kelautan UNDIP, pp. 173-182.

Soltani, M., Parivar, K., Baharara, J., Kerachian, A. A., \& Asili, J. 2014. Hemolytic And Cytotoxic Properties Of Saponin Purified From Holothuria Leucospilota Sea Cucumber. Reports of Biochemistry and Molecular Biology, 3(1):1-8.

Sumarno. 2009. Potensi Ekstrak Daun Sirih Merah (Piper erocatum) Sebagai Antioksidan 
Supriyono. 2008. Kandungan Beta Karoten, Polifenol Total dan Aktivitas Merantas Radikal Bebas Kefir Susu Kacang Hijau (Vigna radiata) oleh Pengaruh Jumlah Starter (Lactobacillus bulgaris dan Candida kefir) dan Konsentrasi Glukosa [Tesis], Universitas Diponogoro, Semarang.

Tursina, L.M. 2011. Uji Antifeedant Ekstrak Kasar Teripang Holothuria atra dan Bohadschia marmorata Terhadap Ikan Karang Di Perairan Pulau Pramuka, Kepulauan Seribu, DKI Jakarta. Universitas Indonesia. Fakultas Matematika dan Ilmu Pengetahuan Alam. Depok.

Wafa, J.A., Adi, T.K., Hanapi, A.A. \& Fasya, A.G. 2014. Penentuan Kapasitas Antioksidan dan Kandungan Fenolik Total Ekstrak Kasar Teripang Pasir (Holothuria scabra) dari Pantai Kenjeran Surabaya. Alchemy, 3(1):76-83.

Wahyuni, D.T. \& Widjanarko, S.B. 2015. Pengaruh jenis pelarut dan lama ekstraksi terhadap ekstrak karotenoid labu kuning dengan metode gelombang ultrasonik. Jurnal Pangan dan Agroindustri. 3(2):390-401.

Yangthong, M., Nongporn, H.T. \& Phromkunthong, W. 2009. Antioxidant Activities of Four Edible Seaweeds from The Southern Coast of Thailand. Plant Foods Human Butrition, 64:218-223. DOI: $10.1007 / \mathrm{s} 11130-009-0127-y$ 